Document downloaded from:

http://hdl.handle.net/10251/39955

This paper must be cited as:

Torregrosa, AJ.; A. Broatch; Pla Moreno, B.; Monico Muñoz, LF. (2013). Impact of Fischer Tropsch and biodiesel fuels on trade-offs between pollutant emissions and combustion noise in diesel engines. Biomass and Bioenergy. 52:22-33.

doi:10.1016/j.biombioe.2013.03.004.

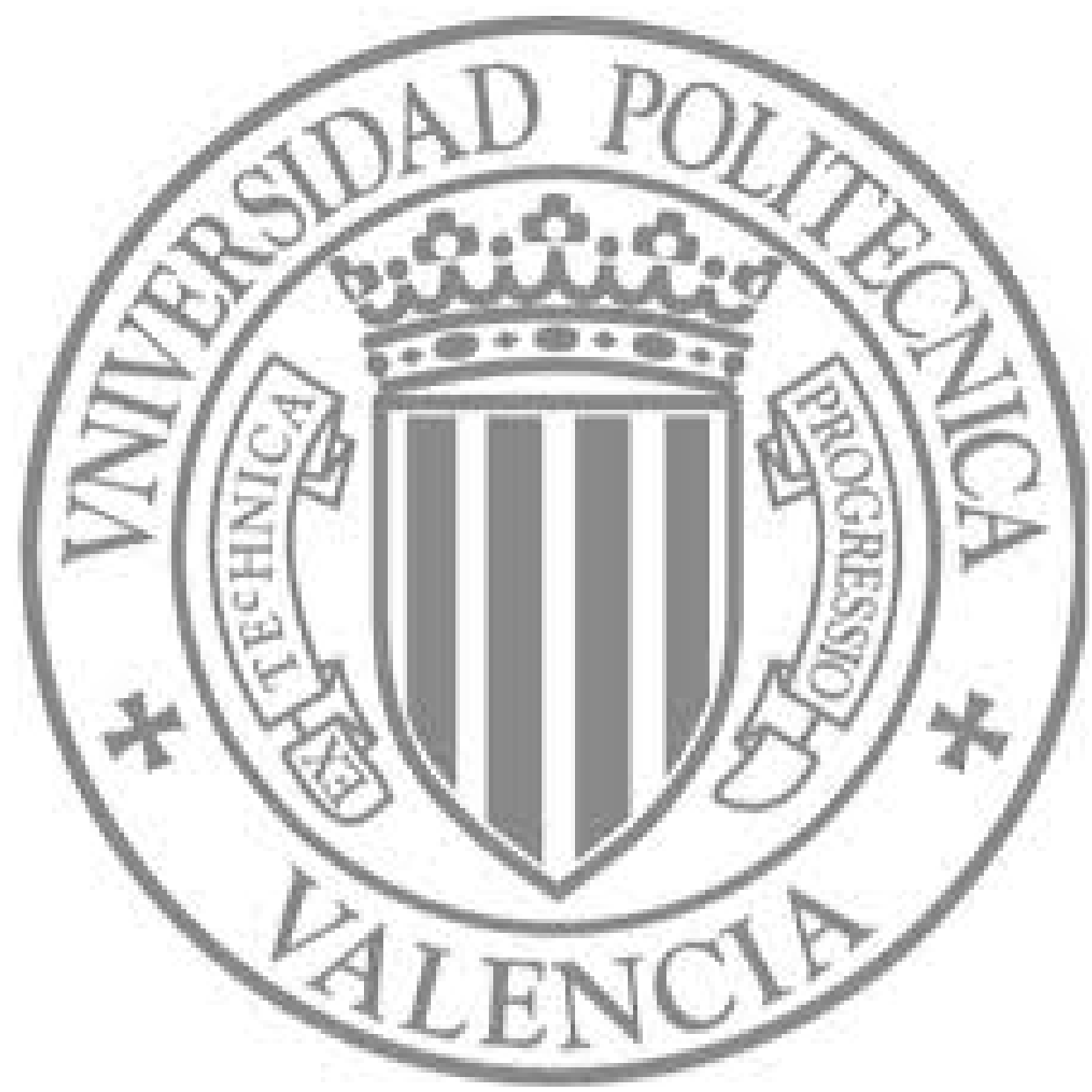

The final publication is available at

http://dx.doi.org/ 10.1016/j.biombioe.2013.03.004

Copyright Elsevier 


\title{
Impact of Fischer-Tropsch and biodiesel fuels on trade-offs between pollutant emissions and combustion noise in Diesel engines
}

\author{
A.J. Torregrosa, A. Broatch*, B. Pla, L.F. Mónico \\ CMT-Motores Térmicos, Universitat Politècnica de València, Aptdo. 22012, E-46071 Valencia, Spain.
}

\begin{abstract}
Over recent decades, direct injection diesel engines have become the propulsion systems most commonly used in automotive vehicles in Europe. Their leading position in the European market is due to improvements in performance, driveability and their capacity for facing the increasingly restrictive standards to which are subject. Nevertheless, their main drawbacks are related to the emission levels, the use of fossil fuels and the engine noise. To mitigate the first two problems, alternative fuels are being used in these engines with encouraging results. The impact of these fuels on engine noise might therefore be analyzed in order to evaluate the feasibility of such a solution. In this work the effect of diverse alternative fuels on emissions, performance and engine noise quality was analyzed. Compared with standard diesel fuel, results show a scarce variation of combustion noise quality whereas soot level decreases, $\mathrm{NO}_{x}$ emissions increase and specific consumption deteriorates.
\end{abstract}

Keywords: Alternative fuels, Exhaust emissions, Diesel engine, Performance, Combustion noise.

\section{Nomenclature \\ Latin: \\ $C_{i} \quad$ coefficients of the combustion noise assessment

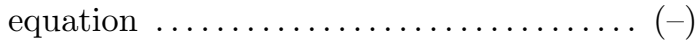 \\ E signal energy $\ldots \ldots \ldots \ldots \ldots \ldots \ldots \ldots(\mathrm{J})$ \\ $I_{1}, I_{2} \quad$ combustion indicators $\ldots \ldots \ldots \ldots \ldots \ldots \ldots(-)$

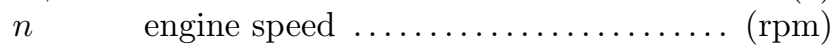 \\ $p \quad$ pressure $\ldots \ldots \ldots \ldots \ldots \ldots \ldots \ldots \ldots \ldots \ldots \ldots \ldots \ldots(\mathrm{Pa})$ \\ $t \quad$ time $\ldots \ldots \ldots \ldots \ldots \ldots \ldots \ldots \ldots \ldots \ldots \ldots \ldots$}

Greek:

$\lambda \quad$ excess of air

Abbreviations:

BSFC brake specific fuel consumption

$\mathrm{CO}$ carbon monoxide

$\mathrm{CO}_{2}$ carbon dioxide

DI direct injection

EGR exhaust gas recirculation

FSN filter smoke number
FT fisher tropsch

ID ignition delay

$\mathrm{NO}_{x} \quad$ nitrogen oxides

$\mathrm{O}_{2} \quad$ oxygen

PCCI premixed charge compression ignition

$\mathrm{RB}$ rapeseed blends

$\mathrm{SB}$ soybean blends

$\mathrm{SO}_{2} \quad$ sulphur dioxide

TDC top dead center

UHC unburned hydrocarbons

\section{Subscripts and Superscripts:}

comb Combustion sub-signal

comp Compression-expansion sub-signal

idle Idle condition

$\max$ Maximum value

res Resonance sub-signal

\section{Introduction}

In recent years, diesel engines have become the most widely used power plant in passenger vehicles in Europe. This fact is mainly due to improvements in driveability, comfort, and to their low fuel consumption. However, in spite of the important advances experienced, these propulsion systems are not free from drawbacks. High levels of pollutants caused by a poorly controlled combustion, the use of fossil fuels, and high levels of radiated noise, are the main problems of this type of engine. To face up these problems, the use of either biodiesel or synthetic fuels (such as Fischer Tropsch) seems to be a feasible alternative
*Corresponding author. Tel.: +34 96 3877650, fax: +34 96 3877659.

Email address: abroatch@mot.upv.es (A. Broatch) 
to the use of fossil fuels.

Fuels obtained from vegetable oil sources appear to be an excellent substitute for petroleum fuel, because of their easy production, utilization, storage, and the significant reduction achievable in pollutant emissions, mainly carbon dioxide $\left(\mathrm{CO}_{2}\right)$. Some studies [1] have shown that biodiesel can reduce net $\mathrm{CO}_{2}$ emissions by $78 \%$ when compared to petroleum diesel. This is due to the closed carbon cycle of biodiesel, in which the $\mathrm{CO}_{2}$ released into the atmosphere when biodiesel is burned is recycled by growing plants, which are later processed into fuel. The sulphur and aromatics content of biodiesel fuels are negligible while their oxygen $\left(\mathrm{O}_{2}\right)$ concentration is substantially high (in the order of $10 \%$ on weight basis) [2]. These characteristics allow significant reductions of sulphur dioxide $\left(\mathrm{SO}_{2}\right)$, soot, carbon monoxide (CO) and unburned hydrocarbons (UHC) $[3,4]$. However, due to their influence on the ignition delay (ID), the production of nitrogen oxides $\left(\mathrm{NO}_{x}\right)$ during combustion is usually increased [5]. In addition, biodiesel fuel is biodegradable, nontoxic, recyclable, locally available, benzene-free and cleaner than fossil fuels $[6,7,8]$. It can be used pure or in different blends because of its miscibility with diesel [9]; it has an excellent lubricity and its use does not require considerable modifications on the engine hardware. Biodiesel can be produced from several oils of different types of oilseed crops, such as those of sunflower, palm, soybean, rapeseed, cottonseed and peanut.

Despite their many advantages, biodiesel have some negative effects on engine operation since its use can have an impact on the injection system (injector coking, fuel lines clogging, etc.), on combustion (poor atomization, carbon deposits, etc.) and on the hardware (piston ring sticking) $[10,11]$. Moreover, due to its higher surface tension and viscosity the cold startability of diesel engines with biodiesel is deteriorated [12]. Some of these effects affect negatively the vaporization process, so that incomplete combustion is induced during the engine start and also an increase of $\mathrm{NO}_{x}$ emissions can be noticed [13]. Additionally, since the heat value of biodiesel is about $13 \%$ lower than that of standard diesel fuel, the brake specific fuel consumption (BSFC) increases while the thermal efficiency is scarcely affected $[14,15]$.

Synthetic fuels like Fischer Tropsch are produced from synthesis gas ( $\mathrm{CO}$ and $\mathrm{H}_{2}$ ), using either natural gas or coal as feedstock. This alternative fuel is characterized by its high cetane number, which leads to short ignition delays $[16,17]$. As in the case of biodiesel, the sulphur and aromatic content of Fisher Tropsh fuel are negligible, so that reductions of $\mathrm{SO}_{2}, \mathrm{CO}, \mathrm{UHC}$ and soot emissions are also expected $[18,19]$. Due to its higher heat value compared with that of a standard diesel fuel, Fischer Tropsch fuel allows also to reduce fuel consumption. Some studies have shown that both the heating value and the fluid-dynamic characteristics of fuel during the injection are the parameters which mostly govern the combustion process and have thus the highest impact on engine performance [20].

Regarding radiated noise, the engine is considered as the main noise source in diesel-powered vehicles due to the characteristic impulsive noise of diesel combustion. For that reason, many efforts have been devoted by car manufactures to mitigate diesel engine noise alongside with the previously commented improvements in performance and driveability. Despite these efforts, current designs are still too noisy, specially during transient operation [21] and new combustion concepts such as the PCCI [22]. While the control of the overall noise is imperative to fulfill the current legislation, sound quality and comfort are essential for the customer purchasing decision [23, 24].

The external sound field of diesel engines comprises the contribution of both combustion and mechanical noise. In these engines, the self-ignition of premixed fuel causes a rapid pressure rise, producing the well known "knock", which excites the gas in the combustion chamber and consequently induces its oscillation $[25,26]$. The source of the combustion noise is related to pressure and mechanical forces, which are characterized by in-cylinder pressure, the system response is associated with the vibration of the block wall, and the radiated noise is the final effect of such a vibration $[27,28]$.

In this investigation the repercussions of alternative fuels (from synthetic and vegetable oils) on engine performance, pollutant emissions $\left(\mathrm{NO}_{x}\right.$ and soot) and combustion noise were analyzed. With this purpose, different biodiesel blends and a synthetic fuel were tested in a lightduty direct injection (DI) diesel engine at different operating conditions. A procedure based on the decomposition of the in-cylinder pressure signal was used in order to evaluate the subjective aspect of combustion noise [23].

\section{Experimental set up}

The experiments of this study were performed on a lightduty 4-cylinder Euro IV turbocharged DI diesel engine, with a total displacement of $1.6 \mathrm{l}$ and common rail injection. The engine was directly coupled to an asynchronous electric brake, which allows controlling the engine speed and load. Engine and injection system specifications are shown in Table 1.

Table 1: Main characteristics of the engine and injector.

\begin{tabular}{lc}
\hline Engine Type & Direct-injection Diesel engine \\
Cylinders & 4 in line \\
Bore $(\mathrm{mm})$ & 75 \\
Stroke $(\mathrm{mm})$ & 88.3 \\
Compression ratio & $18: 1$ \\
Injector nozzle holes & 6 \\
Nozzle holes diameter & 0.124 \\
(mm) & \\
Spray angle $(\mathrm{deg})$ & 150 \\
\hline
\end{tabular}


In order to precisely control engine operation, the temperature of all fluids in the engine was measured with $\mathrm{K}$ type thermocouples; pressure sensors and fuel and air mass flow meters were also used. A Horiba MEXA-720 exhaust gas analyzer was used to measure $\mathrm{NO}_{x}$ emissions, $\mathrm{O}_{2}$ concentration in the exhaust, equivalence ratio and excess of air $(\lambda)$. The $\mathrm{O}_{2}$ concentration in the intake air was measured with a lambda probe located at the intake manifold. Soot emissions were indirectly determined with the correlation proposed by Christian et al. [29] that relates soot and the filter smoke number (FSN). The FSN was measured with an AVL 451S smoke meter.

The pressure trace was measured in all the cylinders with glow-plug piezoelectric transducers. These sensors were calibrated by applying the usual method [30], based on a quasi-steady calibration by means of a deadweight tester with NPL and NIST traceability. Table 2 summarizes the accuracy of the instrumentation used in this work. In-cylinder pressure was recorded with a sampling frequency of $50 \mathrm{kHz}$, so that a bandwidth similar to the human domain of hearing $(20 \mathrm{~Hz}-20 \mathrm{kHz})$ was available. 50 consecutive cycles were recorded for each test.

Table 2: Accuracy of the instrumentation used in this work.

\begin{tabular}{llc}
\hline Sensor & Variable & Accuracy (\%) \\
\hline Piezoelectric & $\begin{array}{l}\text { In-cylinder } \\
\text { pressure } \\
\text { Thermocouples }\end{array}$ & 0.4 \\
& $\begin{array}{l}\text { Temperature of all } \\
\text { fluids }\end{array}$ & 0.35 \\
Encoder & $\begin{array}{l}\text { Engine speed } \\
\text { Exhaust gas }\end{array}$ & 0.006 \\
analyser & $\begin{array}{l}\mathrm{O}_{2} \text { emissions and } \\
\text { concentration in }\end{array}$ & 2 \\
& $\begin{array}{l}\text { the exhaust } \\
\mathrm{O}_{2} \text { concentration } \\
\text { in the intake }\end{array}$ & 1.81 \\
Lambda probe & 3 \\
$\begin{array}{l}\text { Smoke meter } \\
\text { Piezoresistive }\end{array}$ & $\begin{array}{l}\text { FSN } \\
\text { Intake and exhaust } \\
\text { pressure }\end{array}$ & 0.65 \\
$\begin{array}{l}\text { Torque meter } \\
\text { Fuel mass flow } \\
\text { meter }\end{array}$ & Fuel mass \\
$\begin{array}{l}\text { Air mass flow } \\
\text { meter }\end{array}$ & Air mass & 0.1 \\
\hline
\end{tabular}

\section{Methodology}

In order to dispose a sufficiently wide range of engine running conditions, 15 operation points ( 7 conditions at low load, between $5 \%$ to $24 \%$ of full load, and 8 of mid load, between $35 \%$ and $74 \%$ full load) were chosen. These precise conditions were selected because they are represen- tative of those engine operating points during the European MVEG cycle in which combustion noise is critical.

Test were performed with different fuels keeping constant torque. With this purpouse, the quantity of fuel mass injected during the pilot was kept as in the baseline settings whereas the quantity injected in the main injection was varied until the target torque was met. The exhaust gas recirculation (EGR) cooling system of the engine was modified so that a constant intake temperature of $45^{\circ} \mathrm{C}$ was ensured in all the tests. In addition, the intake air mass was also controlled -by setting the EGR valve opening- so that the flow was the same as in the baseline condition (with standard diesel fuel) independently of the alternative fuel used. In this way, one can be sure that any variation of the EGR rate was caused by the fuel itself and not by differences in the air mass flow. Table 3 summarizes the main operating parameters considered in each running point.

With the purpose to define suitable reference conditions, preliminary tests with standard diesel fuel and with the baseline engine settings were performed. From these tests, the reference values of $\mathrm{BSFC}, \mathrm{NO}_{x}$ levels, soot emissions and sound quality of combustion noise were obtained for each of the 15 operation points referred to above. These reference values were compared with those measured with the biodiesel and Fischer Tropsch fuels. The biodiesel fuels used in the tests were six blends of soybean and rapeseed oil with standard diesel fuel in volume concentrations of $30 \%, 50 \%$ and $80 \%$. The synthetic fuel considered in this study was an ester obtained from a Fischer-Tropsch process whose mass composition, determined according to the ASTM D-5291 standard, is 84,7\% carbon, $15 \%$ hydrogen and $0.3 \%$ oxygen. Table 4 shows a summary of the main properties of the different fuels used in the tests. In order to avoid any effect from the fuel used in previous tests, after each test the fuel line was emptied, the main tank was refilled with a different fuel, and then the engine was run at high load for 1 hour before any new measurements were taken.

\subsection{Combustion noise characterization}

The assessment of combustion noise is based on the methodology proposed by Payri et al. [27], in which in-cylinder pressure is decomposed into three sub-signals each one characterizing the relevant phenomena taking place during the operation of diesel engines: compressionexpansion (pseudo-motored signal), combustion, and combustion chamber resonance. The compression-expansion signal does not represent any tendency related to combustion and is used to provide a convenient reference. The combustion signal is influenced by the rate of heat release, which is governed by the injection strategy and engine operating conditions. The resonance signal is associated with the gas oscillation produced by the abrupt pressure rise occurring in the combustion chamber [26]. This decomposition technique was previously applied to the analysis of 
Table 3: Running conditions tested.

\begin{tabular}{|c|c|c|c|c|c|c|c|c|}
\hline \multicolumn{2}{|c|}{ Point } & $\begin{array}{l}\text { Speed } \\
\text { (rpm) }\end{array}$ & $\begin{array}{l}\text { Torque } \\
(\mathrm{Nm})\end{array}$ & $\begin{array}{c}\text { Pilot } \\
\text { timing } \\
\left({ }^{\circ} \mathrm{BTDC}\right)\end{array}$ & $\begin{array}{c}\text { Main } \\
\text { timing } \\
\left({ }^{\circ} \mathrm{BTDC}\right)\end{array}$ & $\begin{array}{c}\text { Pilot } \\
\text { mass } \\
(\mathrm{mg} / \mathrm{str})\end{array}$ & $\begin{array}{c}\text { Injection } \\
\text { pressure } \\
\text { (bar) }\end{array}$ & $\begin{array}{c}\text { Air mass } \\
\text { flow } \\
(\mathrm{kg} / \mathrm{h})\end{array}$ \\
\hline \multirow{7}{*}{$\begin{array}{l}\text { Low } \\
\text { load }\end{array}$} & 1 & 1500 & 38 & 25.28 & -3.00 & 1.62 & 859 & 45.1 \\
\hline & 2 & 1900 & 20 & 25.05 & -0.65 & 1.54 & 666 & 45.4 \\
\hline & 3 & 1900 & 50 & 27.50 & -0.66 & 1.62 & 850 & 60.0 \\
\hline & 4 & 2250 & 13 & 27.89 & 1.50 & 1.58 & 687 & 86.8 \\
\hline & 5 & 2400 & 50 & 30.21 & 3.00 & 1.65 & 900 & 117.7 \\
\hline & 6 & 2850 & 20 & 32.80 & 5.50 & 1.29 & 516 & 158.2 \\
\hline & 7 & 2850 & 50 & 33.00 & 6.80 & 1.60 & 795 & 170.8 \\
\hline \multirow{8}{*}{$\begin{array}{l}\text { Mid } \\
\text { load }\end{array}$} & 8 & 1500 & 76 & 27.80 & -1.17 & 1.76 & 1035 & 62.3 \\
\hline & 9 & 1500 & 152 & 31.78 & 3.60 & 1.77 & 1050 & 104.8 \\
\hline & 10 & 1900 & 127 & 33.35 & 4.33 & 1.90 & 1212 & 104.1 \\
\hline & 11 & 1900 & 152 & 34.28 & 5.55 & 1.90 & 1215 & 127.3 \\
\hline & 12 & 2280 & 104 & 33.98 & 5.00 & 1.92 & 1250 & 120.1 \\
\hline & 13 & 2400 & 152 & 37.66 & 9.51 & 1.94 & 1288 & 198.6 \\
\hline & 14 & 2850 & 89 & 35.20 & 8.41 & 1.87 & 1119 & 188.8 \\
\hline & 15 & 2850 & 152 & 38.60 & 11.15 & 1.98 & 1238 & 221.0 \\
\hline
\end{tabular}

cause-effect relations between the source (caused by combustion) and both the objective and subjective aspects of noise $[23,24]$. In this investigation, the procedure proposed by Payri et al., was used to predict the sound quality of the combustion noise, which is quantified by a mark as would be given by a jury during a listening test as is described in [23]. According to this procedure, the mark is highly correlated with two combustion indicators. The first one, $I_{1}$, is related to the sudden in-cylinder pressure rise and is expressed mathematically by:

$$
I_{1}=\frac{n}{n_{\text {idle }}}\left[\frac{\left(d p_{\max 1} / d t\right)_{c o m b}+\left(d p_{\max 2} / d t\right)_{c o m b}}{\left(d p_{\max } / d t\right)_{c o m p}}\right]
$$

where $n$ and $n_{\text {idle }}$ are the actual speed and idle speed, respectively; $\left(d p_{\max 1} / d t\right)_{\text {comb }}$ and $\left(d p_{\max 2} / d t\right)_{\text {comb }}$ represent the two maximum values corresponding to the two higher peaks of the pressure derivative curve during combustion, and $\left(d p_{\max } / d t\right)_{\text {comp }}$ is the peak value of the pressure derivative corresponding to the compressionexpansion component.

The second indicator, $I_{2}$, quantifies the contribution of the resonance in the combustion chamber through the energy of the high frequency content of the in-cylinder pressure trace $[26,31]$. It is expressed by:

$$
I_{2}=\log \left[E_{0} \frac{E^{r e s}}{E^{c o m p}}\right]
$$

where $E_{0}$ is a convenient scaling factor, $E^{r e s}$ is the signal energy of the resonance and $E^{c o m p}$ is the signal energy of the compression-expansion.

With these indicators, the sound quality of the combustion noise can be assessed by a mark ranging from 0 to
10 -which represents the satisfaction degree of an average customer- through the following correlation:

$$
\text { Mark }=10-C_{1} I_{1}-C_{2} I_{2}
$$

where $C_{i}$ are coefficients dependent on the engine family and size.

\section{Results and discussion}

The results of EGR rate, fuel consumption, emission levels and combustion noise quality measured during the engine tests defined in the methodology are presented and analyzed in this section. Contour plots were drawn in order to determine the relationship among each one of these variables and the engine torque and speed for the tested fuels: standard diesel, biodiesel blends and Fischer Tropsch.

The EGR rate is one of the most important parameters affecting engine efficiency, emissions and noise. Fig. 1 shows the EGR maps as function of engine speed and torque for the fuels tested. For all the fuels, the highest EGR rates were used in the low speed-torque range since it covers a wide part of the operating area during the homologation cycle (i.e. MVEG). As either torque or engine speed increases the EGR rate diminishes progressively. Comparing the results obtained with different fuels, some differences in the EGR rate are observed. Despite the tests were performed keeping constant air mass flow rate, some differences in intake pressure were observed. Variations in the intake pressure at similar speeds and loads are due to different turbocharging conditions, which are induced by the different exhaust temperature obtained with diesel, biodiesel and Fischer Tropsch fuels. Since the mass 
Table 4: Properties of fuels used.

\begin{tabular}{ccccc}
\hline $\begin{array}{c}\text { Fuel } \\
\text { (in volumetric concentrations) }\end{array}$ & $\begin{array}{c}\text { Density } 15^{\circ} \mathrm{C} \\
\left(\mathrm{kg} / \mathrm{m}^{3}\right)\end{array}$ & $\begin{array}{c}\text { Cetane } \\
\text { index }\end{array}$ & $\begin{array}{c}\text { Viscosity } 40^{\circ} \mathrm{C} \\
(\mathrm{cSt} / \mathrm{seg})\end{array}$ & $\begin{array}{c}\text { Calorific value } \\
\left(\mathrm{MJ} \mathrm{kg}^{-1}\right)\end{array}$ \\
\hline D: 100\% Diesel & 839.3 & 51.2 & 2.676 & 45.200 \\
SB30: 30\% Soybean/70\% D & 855.4 & 51.7 & 3.419 & 43.619 \\
SB50: 50\% Soybean/50\% D & 866.9 & 52.1 & 3.571 & 42.547 \\
SB80: 80\% Soybean/20\% D & 874.1 & 59.4 & 3.958 & 40.705 \\
RB30: 30\% Rapeseed/70\% D & 854.2 & 52.1 & 3.496 & 43.658 \\
RB50: 50\% Rapeseed/50\% D & 865.0 & 52.7 & 3.636 & 42.412 \\
RB80: 80\% Rapeseed/20\% D & 873.9 & 60.0 & 4.094 & 40.698 \\
FT: $100 \%$ Fischer Tropsch & 772.0 & 78.1 & 2.785 & 47.010 \\
\hline
\end{tabular}

induced depends on the intake pressure, for given engine operating conditions, the EGR rate must be different due to the effect of the fuel on the exhaust temperature. The highest EGR rates were measured at low load and speed with standard diesel fuel. Conversely the lowest EGR rates were measured with Fischer Tropsch fuel at almost the whole operating range of the engine. Finally, these differences in the EGR rate have a relevant impact on the performance parameters that will be analyzed in the following sections.

\subsection{Effect on $B S F C$}

Fig. 2 shows that the BSFC increases when the engine runs with biodiesel fuels. In agreement with the literature [19], the differences in BSFC are due to the lower heating value of biodiesels, while engine thermal efficiency is almost unaffected by the use of this kind of fuels. According to Table 3, the heating value of the biodiesel blend decreases in proportion to the biodiesel content and hence the BSFC increases. Since the heating value of both soybean and rapeseed biodiesels was quite similar (see Table 3) the BSFC of the engine is scarcely sensitive to the type of biodiesel fuel used. In addition, since their density, viscosity and cetane number are also similar, any difference in the injection rate and combustion behaviour which could cause variations of engine efficiency is not expected.

Regarding the Fischer Tropsch fuel, its higher heating value leads to a noticeable fuel saving despite thermal efficiency is not increased. The results shown in Fig. 2 indicate that the BSFC of the engine at mid loads and low speeds can be reduced by almost $20 \mathrm{~g} / \mathrm{kWh}$ when using this synthetic fuel.

It must be remarked that the combustion settings considered were optimized in order to run the engine with standard diesel fuel. Therefore, parameters such as injection pressure, injection timing and EGR rate amongst others were set to maximize the engine efficiency and minimize emissions and noise when standard diesel fuel was used. Since both biodiesel and Fischer Tropsch properties differ from those of standard diesel, the engine should be recalibrated in order to obtain the optimum trade-off between performance, pollutant emissions and noise for each fuel, so that results better than those previously discussed should be expected. Nevertheless, engine recalibration is out of the scope of this study.

\subsection{Effect on soot emissions}

Soot emission levels are presented in Fig. 3. These results show that independently of the fuel used, the maximum soot levels are obtained at the zones of high torque and speed, where power demands cause a reduction in the air to fuel ratio. Soot emissions also become important when maximum EGR rates are used due to the substantial reduction of the $\mathrm{O}_{2}$ concentration in the combustion chamber in such conditions.

Regarding the impact of the biodiesel on soot emissions, results in Fig. 3 also show an important reduction in comparison with the standard diesel fuel. Moreover, the reduction is more apparent as the biodiesel content of the fuel blend increases. According to Lapuerta et al. [32], the oxygen contents in biodiesel fuels is the factor with a higher impact on this reduction, since it allows a more complete combustion in zones of the combustion chamber with low air to fuel ratios and hence soot oxidation is enhanced. The fact that biodiesel is sulphur- and aromaticsfree -both compounds are soot precursors- is another reason why soot emissions can be reduced with these fuels. Comparing the two types of biodiesel fuel tested, similar emission levels were measured in both cases. Nevertheless, when comparing both types of biodiesel fuels, the results shown that soy achieved a higher reduction in soot emissions.

With the Fischer Tropsch fuel, lower soot emission levels than those obtained with standard diesel were also measured. However, these levels are higher than those obtained with any of the biodiesel fuels. Since the oxygen content of Fischer Tropsch fuel is zero, the reduction in soot emissions should be attributed to other effects than those promoted by the excess of oxygen during combustion. Despite the higher heating value of Fischer Tropsch causes a lower fuel-to-air ratio in tests as the air mass flow was kept constant, it should be noticed that since the Fischer Tropsch has a lower stoichiometric fuel-to-air ratio than diesel fuel (1/14.92 and 1/14.54, respectively), the 

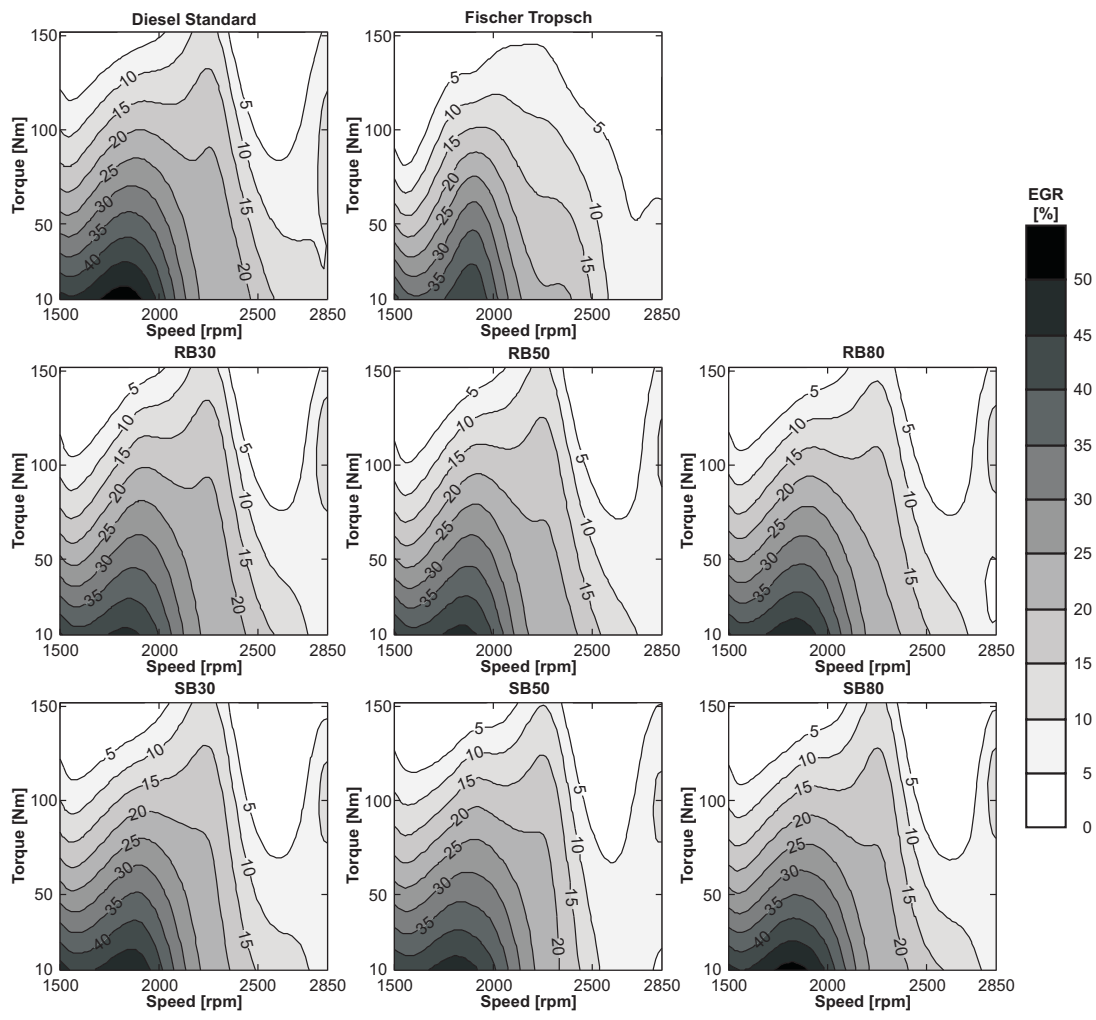

Figure 1: Contours of measured EGR rate for different fuels.
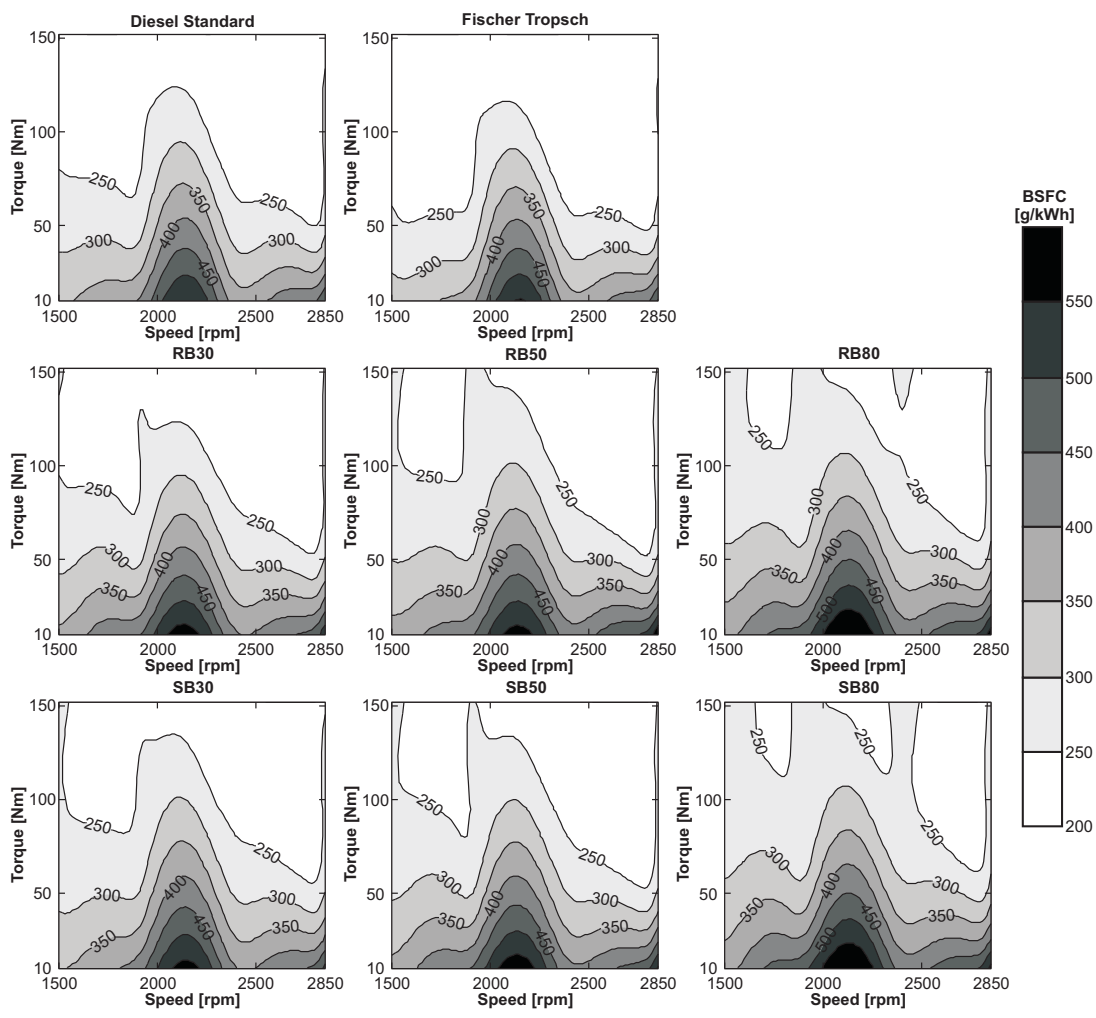

Figure 2: Contours of BSFC for different fuels. 

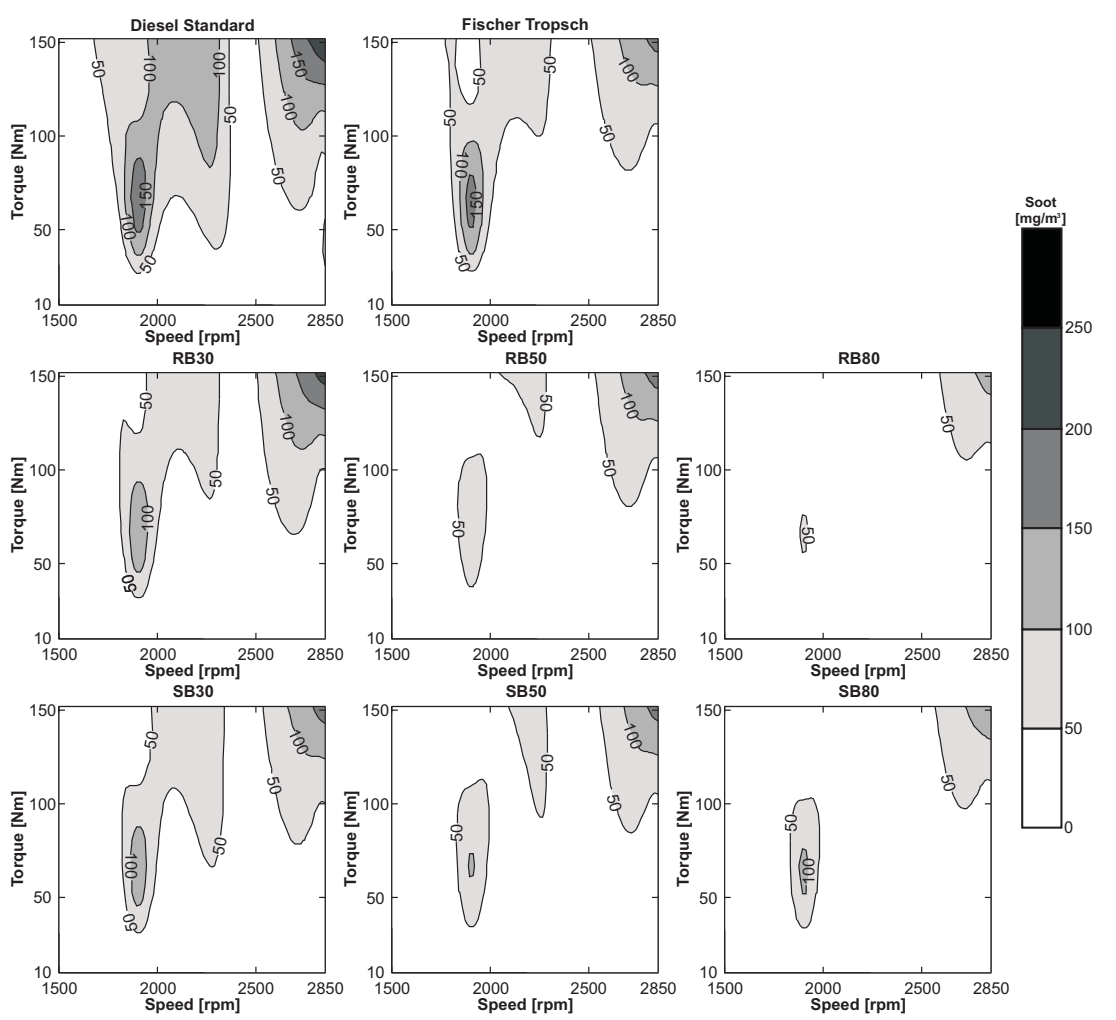

Figure 3: Contours of soot emissions for different fuels.

soot reduction cannot be attributed to a higher excess of air. Indeed, this reduction must be related to the fact that Fischer Tropsch is a sulphur-free fuel and has less aromatics than standard diesel.

\subsection{Effect on $N O_{x}$ emissions}

The measured $\mathrm{NO}_{x}$ emissions for the fuels tested are shown in the plots in Fig. 4. The emission pattern measured with the standard diesel fuel shows that $\mathrm{NO}_{x}$ increases as the load rises due to the higher combustion pressure and temperature. Particularly, points with lower torque than $100 \mathrm{Nm}$ and engine speeds up to $2250 \mathrm{rpm}$ have lower $\mathrm{NO}_{x}$ emissions due to the high EGR rates considered at these conditions (see Fig. 1). For the rest of fuels tested similar $\mathrm{NO}_{x}$ emission patterns were also measured.

Unlike the clear trends obtained for BSFC and soot, the impact of biodiesel fuel on $\mathrm{NO}_{x}$ emissions is more difficult to analyze. At low load, tests with biodiesel fuels show $\mathrm{NO}_{x}$ emissions similar to those with standard diesel despite the slightly lower EGR rate shown in Fig. 1. However, as load increases $\mathrm{NO}_{x}$ emissions with biodiesel fuel increase faster and hence, biodiesel blends produce higher $\mathrm{NO}_{x}$ emissions than standard diesel fuel at high load. The $\mathrm{NO}_{x}$ emissions obtained with both types of biodiesel are almost equal due to their similar properties. Moreover, the results show that increasing the biodiesel content of the blend, $\mathrm{NO}_{x}$ emissions are scarcely affected.
In spite that most of the results available in the literature show that $\mathrm{NO}_{x}$ emissions are deteriorated with biodiesel fuel, there is not a single explanation for such behaviour. The reason for this lack of agreement is that the $\mathrm{NO}_{x}$ increase experimented with biodiesel fuel is not related to a single physical property, but rather is the result of a set of properties whose effects may counteract or promote each other depending on the operating conditions.

The increase in $\mathrm{NO}_{x}$ emissions is frequently attributed to the advanced injection timing caused by the higher bulk modulus of compressibility of biodiesel that modifies the propagation speed of the fuel pressure wave in the injection system [32]. This phenomenon affects to fuel injector pumps but its impact on common-rail systems such as that used in this study should be minimum. Differences in fuel density also affect the fuel injection rate since for a given injection duration, the mass fuel rate of a heavier fuel is higher [33]. Additionally, the effect of the radiative heat transfer from soot in the combustion chamber on $\mathrm{NO}_{x}$ formation must also be considered. It is known that soot radiation may reduce the combustion temperature and consequently $\mathrm{NO}_{x}$ emissions should be reduced [32]. However, due to the lower soot formation during the combustion of biodiesel fuels, the opposite effect should be expected so that in-cylinder temperature during combustion is increased and consequently the $\mathrm{NO}_{x}$ formation increases. $\mathrm{NO}_{x}$ emissions are also sensitive to the cetane number of the fuel. The higher cetane number 

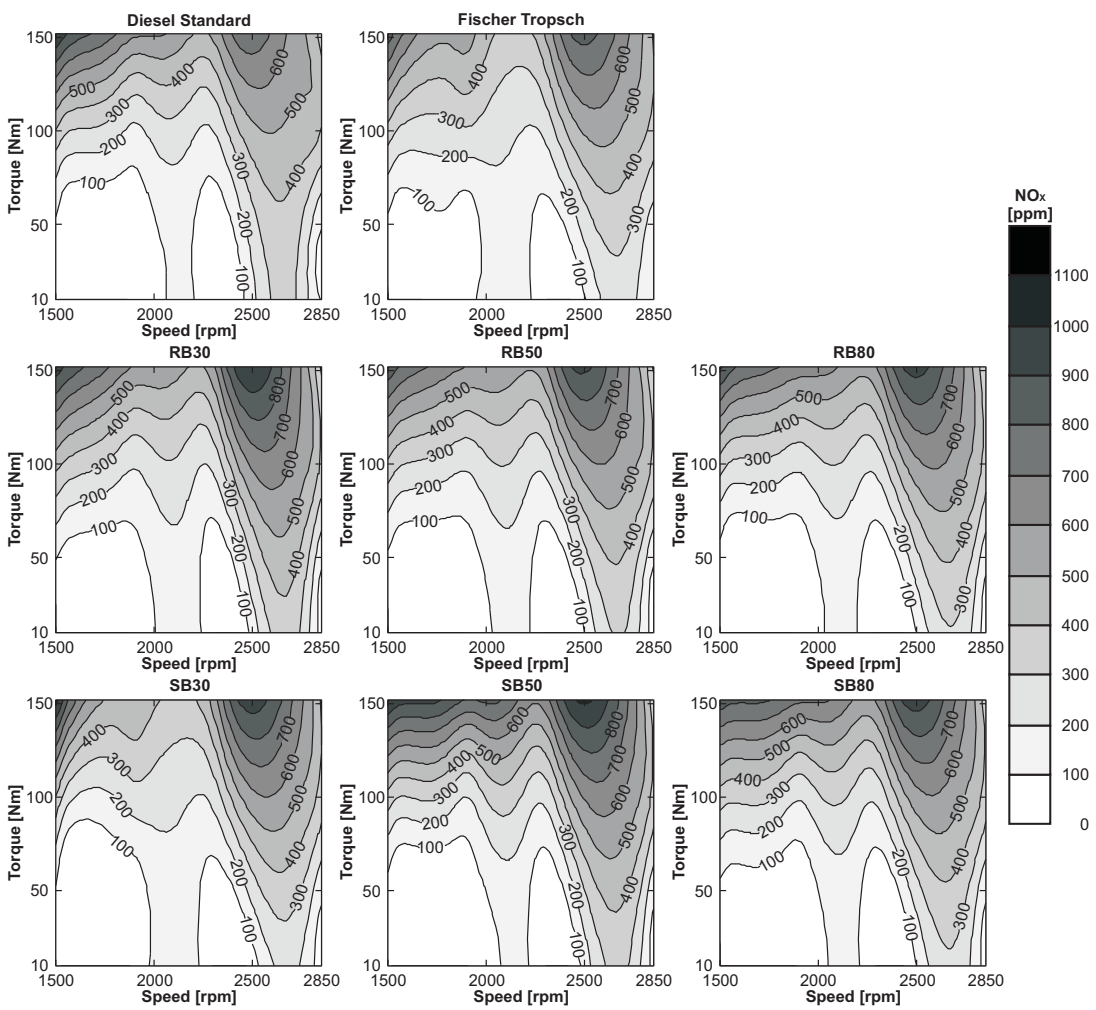

Figure 4: Contours of $\mathrm{NO}_{x}$ emissions for different fuels.

of biodiesels, compared to standard diesel fuel, affects the combustion process reducing the amount of fuel burned in the premixed phase, thus contributing to lower temperatures and hence lower $\mathrm{NO}_{x}$ emissions. This positive effect of biodiesel on $\mathrm{NO}_{x}$ emissions can be observed at low loads; however, as reported by other authors [32, 33], at medium to high loads $\mathrm{NO}_{x}$ emissions are not affected by cetane number.

The effect of Fischer Tropsch on $\mathrm{NO}_{x}$ emissions is similar to that obtained with biodiesel fuels, since Fischer Tropsch presents an earlier combustion and its soot emissions are also lower.

Finally, it should be remarked that $\mathrm{NO}_{x}$ emissions are quite sensitive to the EGR rate and, therefore, slight differences in the EGR rate and composition between tests may also cause noticeable differences in the $\mathrm{NO}_{x}$ emission levels [34].

\subsection{Effect on the combustion noise quality}

Fig. 5 shows the characteristic mark of the sound quality of combustion noise calculated with the procedure described in section 3.1 for all the fuels tested. Taking into account that a mark of 7 specifies the comfort limit for combustion noise, these results evidence that the engine noise at the considered operating conditions is a critical issue and therefore should be improved. Independently of the fuel used, this limit was surpassed only at low loads. As the load increased, the mark decreased to unacceptable values due to the faster pressure rise during the combustion process.

The results in Fig.5 show that the combustion noise quality is deteriorated -lower mark- as the biodiesel content in the fuel blend increases. In addition, the sound quality of combustion noise with soybean is somewhat better than with rapeseed oil. Differences in combustion phasing and injection shape explain the higher pressure rise as the biodiesel content increases, and therefore the deterioration of the sound quality of combustion noise. Fig. 6a and $\mathrm{b}$ evidence that in-cylinder pressure and the rate of the fuel burning -represented by the pressure derivative of the combustion signal for $2400 \mathrm{rpm}$ and $152 \mathrm{Nm}$ - advance when any any biodiesel or Fischer Tropsch fuels are used. These differences contribute to the noise deterioration.

The mark is reduced by almost a $13 \%$ when the Fischer Tropsch fuel is used. Despite its lower density, its higher heating power forced to use shorter injection timings, so that the injected mass of fuel was kept constant. Therefore more fuel burned in premixed combustion phase is expected and thus higher rates of in-cylinder pressure rise during combustion are produced.

Apart from the above reasons, the lower EGR rates measured during tests with biodiesel and Fischer Tropsch fuel also contribute to reduce the ID, thus increasing the impact on the engine noise. 

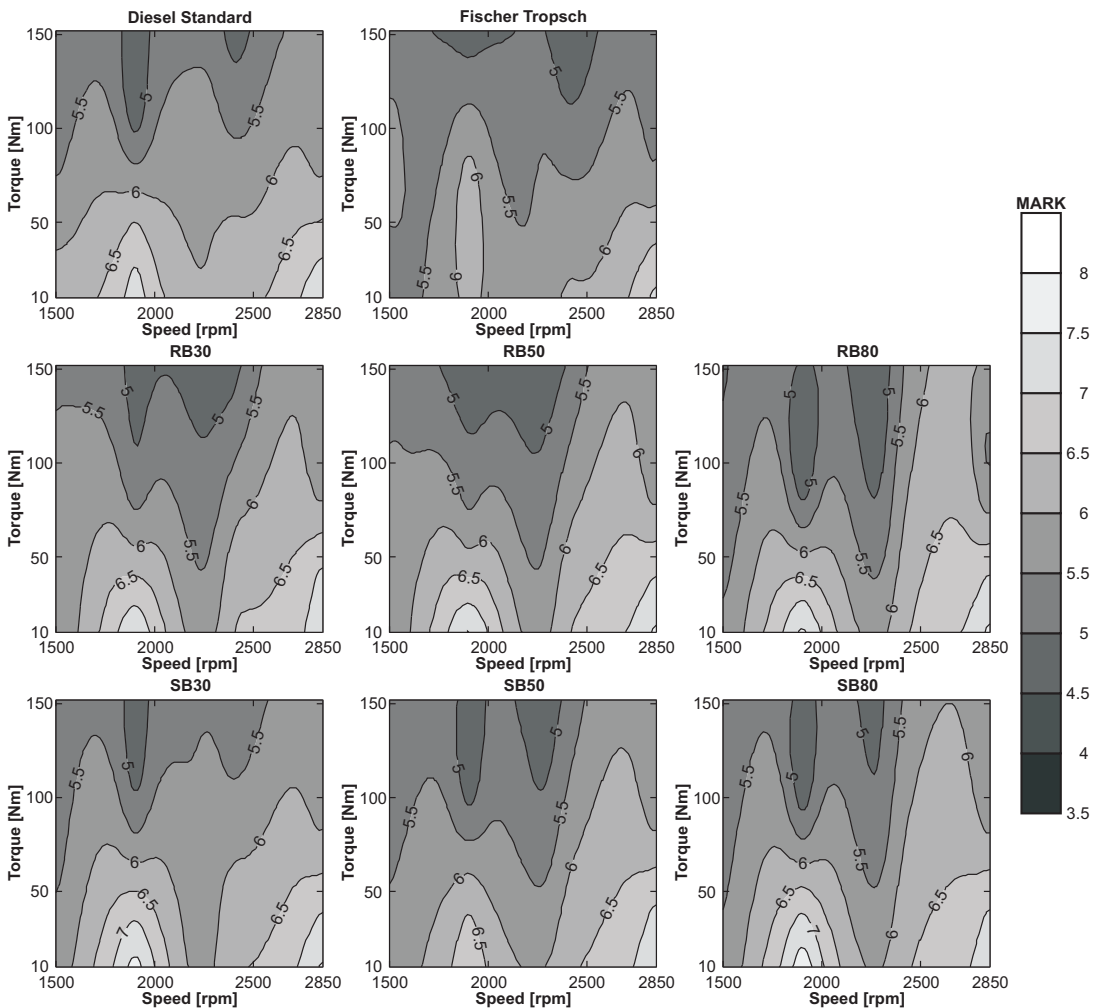

Figure 5: Contours of sound quality mark of combustion noise for different fuels.
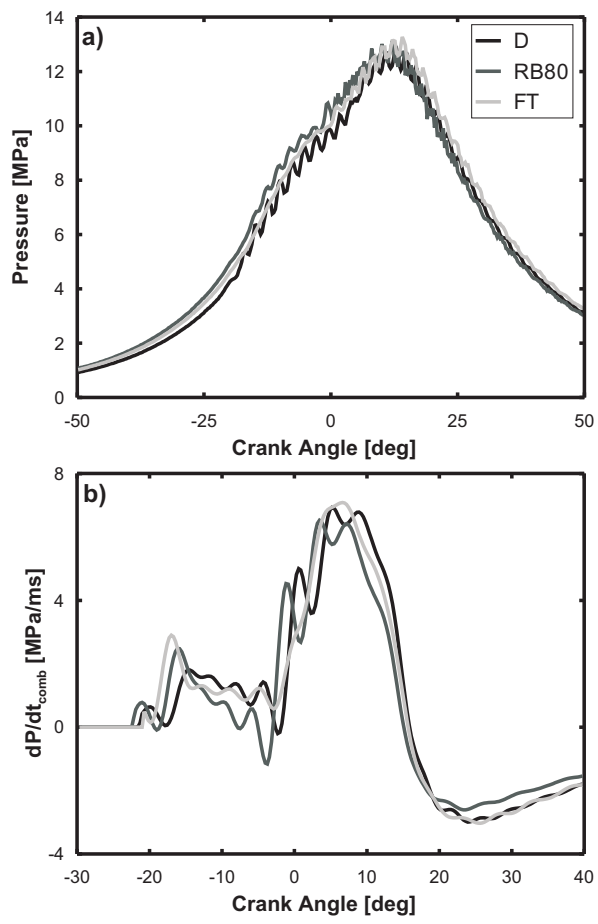

Figure 6: Effect of fuel on: in-cylinder pressure (a) and in-cylinder pressure derivative (b).

\subsection{Effect of EGR rate}

The analysis presented in the previous sections has shown that BSFC, soot, $\mathrm{NO}_{x}$ and combustion noise quality are very sensitive to the EGR rate. The purpose of this section is to perform a deeper analysis of the impact of EGR rate on these parameters in order to evaluate the feasibility of defining optimal EGR settings for the improvement of those parameters when biodiesel fuel is used. With this purpose, the EGR rate was varied actuating on the EGR valve while the rest of the engine parameters -which were optimized for standard diesel fuel- were kept equal to the baseline settings. The tests were performed at $1500 \mathrm{rpm}$ and $38 \mathrm{Nm}$ torque with the three rapeseed based biodiesel blends considered.

The sensitivity of emissions and noise to both EGR rate variation and biodiesel content is represented in Fig. 7 . These results evidence that the reduction of the $\mathrm{O}_{2}$ concentration of the charge due to the EGR rate shifts the whole combustion process further towards the expansion stroke. Due to this fact both the combustion temperature and the rate of pressure rise in the cylinder can be reduced, which allows a decrease in the $\mathrm{NO}_{x}$ formation and an improvement in combustion noise, respectively. Nevertheless, since the EGR causes low local oxygen to fuel ratios, soot emissions are increased. Moreover, the reduction of the oxygen availability in the cylinder produces also an increase in BSFC.

Fig. 7 also shows that for a given EGR rate, soot emis- 


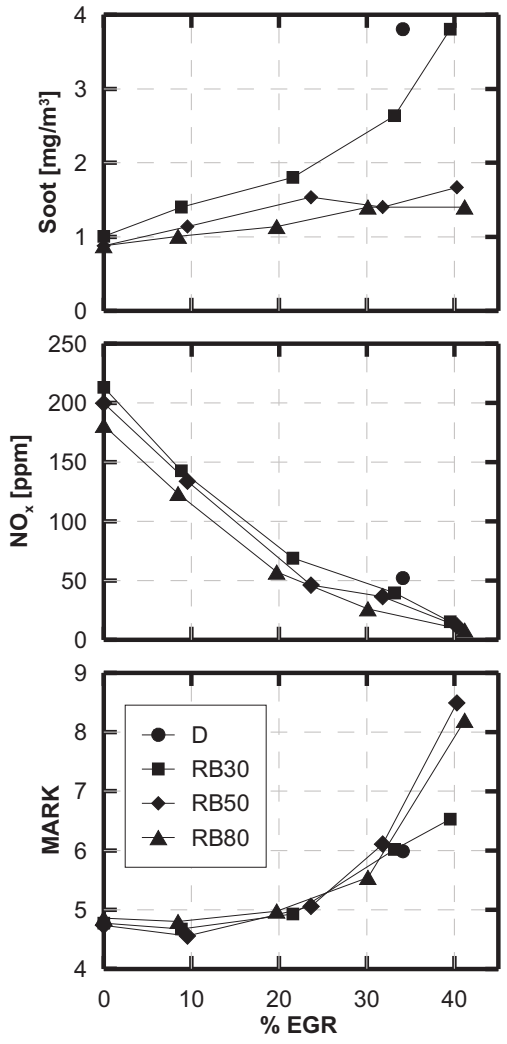

Figure 7: Effect of EGR rate on emissions and noise for different rapeseed blends.

sions decrease as the biodiesel content increases. The soot reduction is more apparent for blends containing more than $50 \%$ of biodiesel. Regarding $\mathrm{NO}_{x}$ and noise quality the effect of the fuel blend composition is not as evident as for the case of soot emissions. For the low range of EGR rates a noticeable reduction of $\mathrm{NO}_{x}$ emissions can be appreciated. These differences seem to be smaller as the EGR rate increases because very low levels were measured at these conditions. The opposite trend is observed for the combustion noise, which notably improves for higher EGR rates.

Finally, results in Fig. 7 indicate that by increasing the EGR rate from the baseline (32\%) to $35 \%$ acceptable levels (7) of the noise quality can be achieved, and soot and $\mathrm{NO}_{x}$ emissions are reduced when either rapeseed blends RB50 or RB80 are used. In order to reach the acceptable limit of combustion noise with the RB30 blend, an EGR rate higher than $40 \%$ must be used, but then soot would exceed the level emitted with standard diesel fuel and an increase of BSFC of more than $27 \%$ should be expected.

\section{Conclusions}

This investigation confirmed that biodiesel fuels are very appropriate substitute for oil fuels and suitable for reducing pollutant emissions in diesel engines. However, their potential in base-line diesel engines for environmental preservation could be missed due to their low values of sound quality, which is an aspect most oftenly considered by the customers during their purchasing decision of vehicles powered by diesel engines. This fact puts in evidence that further work is still required to adapt the engine settings to the alternative fuels and the importance of incorporating combustion noise issues together with performance and emissions requirements during the definition of such settings.

Since biodiesel fuels have heating values lower than that of standard diesel, the brake specific fuel consumption is deteriorated with these fuels, but the engine efficiency is just slightly affected. In addition, consumption increases in proportion to the biodiesel content in the blend. Conversely, the synthetic Fischer Tropsch fuel permits a noticeable reduction in the fuel consumption of the engine.

Regarding pollutant emissions, the results showed a great potential of biodiesel and Fischer Tropsch fuels for reducing soot emissions in comparison to the standard diesel fuel. Soot emission reduction is increased as the proportion of biodiesel in the blend is larger. On the contrary, $\mathrm{NO}_{x}$ emissions increase mainly due to the higher combustion pressure and temperature induced by changes in injection rate and combustion phasing.

From the acoustic point of view, combustion noise is sensitive to both biodiesel and synthetic fuels. The results showed that combustion noise was deteriorated as the biodiesel percentage in the blend increases. Moreover, a more apparent deterioration of the sound quality of combustion noise was observed with the Fischer Tropsch fuel. In both cases, differences in combustion phasing and injection rate are the cause of noise deterioration.

Finally, in order to reduce $\mathrm{NO}_{x}$ emission and improve the sound quality of engine noise with biodiesel fuels, high EGR rates are imperatively required. The experiments showed that good trade-offs between pollutant emissions and noise can be reached with EGR rates of $35 \%$ and with RB50 and RB80 blends. Despite the increase of soot emissions that may be expected with these strategies, the levels were still lower than those obtained with standard diesel fuel.

\section{Acknowledgements}

This work has been partially supported by Ministerio de Educación y Ciencia through grant No. TRA200613782. L.F. Mónico holds the grant 2009/003 from Santiago Grisolía Program of Generalitat Valenciana.

\section{References}

[1] Senatore A, Cardone M, Buono D. Combustion study of a common rail diesel engine optimized to be fueled with biodiesel. Energ Fuel 2008;22:1405-10.

[2] Muncrief RL, Rooks CW, Cruz M, Harold MP. Combining biodiesel and exhaust gas recirculation for reduction in $\mathrm{NOx}$ and particulate emissions. Energ Fuel 2008;22:1285-96. 
[3] Thompson GJ, Nuszkowski J. Neat fuel influence on biodiesel blend emissions. Int J Engine Res 2010;11:61-77.

[4] Hribernik A, Kegl B. Influence of biodiesel fuel on the combustion and emission formation in a direct injection (DI) diesel engine. Energ Fuel 2007;21:1760-7.

[5] Bermúdez V, Luján JM, Pla B, Linares WG. Comparative study of the regulated and unregulated gaseous emissions during NEDC in a light-duty diesel engine fuelled with fischer tropsch and biodiesel fuels. Biomass Bioenergy 2011;35:789-98.

[6] Anand K, Sharma R.P, Mehta PS. Experimental investigations on combustion, performance and emissions characteristics of neat karanji biodiesel and its methanol blend in a diesel engine. Biomass Bioenergy 2011;35:533-41.

[7] Saravanan N, Nagarajan G, Puhan S. Experimental investigation on a DI diesel engine fuelled with Madhuca Indica ester and diesel blend. Biomass Bioenergy 2010;34:838-43.

[8] Tormos B, Novella R, García A, Gargar K. Comprehensive study of biodiesel fuel for HSDI engines in conventional and low temperature combustion conditions. Renewable Energy 2010;35:368-78.

[9] Bunce M, Snyder D, Adi G, Hall C, Koehler J, Davila B, Kumar S, Garimella P, Stanton D, Shaver G. Stock and optimized performance and emissions with 5 and $20 \%$ soy biodiesel blends in a modern common rail turbo-diesel engine. Energ Fuel 2010;24:928-39.

[10] Gumus M, Kasifoglu S. Performance and emission evaluation of a compression ignition engine using a biodiesel (apricot seed kernel oil methyl ester) and its blends with diesel fuel. Biomass Bioenerg 2010;34:134-9.

[11] Monyem A, Van Gerpen JH. The effect of biodiesel oxidation on engine performance and emissions. Biomass Bioenerg 2001;20:317-25.

[12] Mondal P, Basu M, Balasubramanian N. Direct use of vegetable oil and animal fat as alternative fuel in internal combustion engine. Biofuels, Bioprod. Biorefin 2008;2:155-74.

[13] Yahya A, Marley S. Performance and exhaust emissions of a compression ignition engine operating on ester fuels at increased injection pressure and advanced timing. Biomass Bioenerg 1994;6:297-319.

[14] Luján JM, Bermúdez V, Tormos B, Pla B. Comparative analysis of a DI diesel engine fuelled with biodiesel blends during the European MVEG-A cycle: Performance and emissions (II). 2009;33:948-56.

[15] Luján JM, Tormos B, Salvador FJ, Gargar K. Comparative analysis of a DI diesel engine fuelled with biodiesel blends during the European MVEG-A cycle: Preliminary study (I). Biomass Bioenergy 2009;33:941-7.

[16] Basha SA, Gopal KR, Jebaraj S. A review on biodiesel production, combustion, emissions and performance. Renewable Sustainable Energy Rev 2009;13:1628-34.

[17] Tijmensen MJA, Faaij APC, Hamelinck CN, van Hardeveld MRM. Exploration of the possibilities for production of Fischer Tropsch liquids and power via biomass gasification. Biomass Bioenergy 2002;23:129-52.

[18] Aizawa T, Kosaka H. Effects of Fischer-Tropsch diesel fuel on soot formation processes in a diesel spray flame. Int. J. Engine Res 2010;11:79-87.

[19] Lapuerta M, Armas O, Hernández JJ, Tsolakis A. Potential for reducing emissions in a diesel engine by fuelling with conventional biodiesel and Fischer-Tropsch diesel. Fuel 2010;89:310613.

[20] Desantes JM, Payri R, García A, Manin J. Experimental study of biodiesel blends' effects on diesel injection processes. Energ Fuel 2009;23:3227-35.

[21] Payri F, Torregrosa AJ, Broatch A, Monelletta L. Assessment of Diesel combustion noise overall level in transient operation. Int. J. Automot. Technol 2009;10:761-9.

[22] Torregrosa AJ, Broatch A, Novella R, Mónico LF. Suitability analysis of advanced diesel combustion concepts for emissions and noise control. Energy 2011;36:825-38.

[23] Payri F, Broatch A, Margot X, Monelletta L. Sound quality assessment of diesel combustion noise using in-cylinder pressure components. Meas. Sci. Technol 2009;20:015107,(12pp).

[24] Torregrosa AJ, Broatch A, Martín J, Monelletta L. Combustion noise level assessment in direct injection diesel engines by means of in-cylinder pressure components. Meas. Sci. Technol 2007;18:2131-21.

[25] Pruvost L, Leclère Q, Parizet E. Diesel engine combustion and mechanical noise separation using an improved spectrofilter. Mech. Syst. Sig. Process 2009;23:2072-87.

[26] Torregrosa AJ, Broatch A, Margot X, Marant V, Beauge Y. Combustion chamber resonances in direct injection automotive diesel engines: A numerical approach. Int. J. Engine Res 2004;5:83-91.

[27] Payri F. Broatch A, Tormos B, Marant V. 2005. New methodology for in cylinder pressure analysis in direct injection diesel engines - application to combustion noise. Meas. Sci. Technol 2005; $16: 540-7$.

[28] Anderton D. Relation between combustion system and noise. SAE Tech Pap;1979. 790270.

[29] Christian VR, Knopf F, Jaschek A, Schindler W. Eine neue Me $\beta$ methodik der Bosch-Zahl mit erhörter Empfindlichkeit, MTZ Motortech 1993;54:16-22.

[30] Tichý, J.; Gautschi, G. Piezo-Elektrische Me $\beta$ technik; Springer: Berlin, 1980.

[31] Broatch A, Margot X, Gil A, Donayre C. Computational study of the sensitivity to ignition characteristics of the resonance in DI diesel engine combustion chambers. Eng. Comput 2007;24(12):77-96.

[32] Lapuerta M, Armas O, Rodríguez-Fernández J. Effect of biodiesel fuels on diesel engine emissions. Prog. Energy Combust. Sci 2008;34:198-223.

[33] Xiaobin L, Ömer LG. Effects of fuel cetane number, density and aromatic content on Diesel engine $N O_{x}$ emissions at different operating conditions. The Fourth International Symposium COMODIA, 1998:111-6.

[34] Tsolakis A, Megaritis A, Wyszynski ML, Theinnoi K. Engine performance and emissions of a diesel engine operating on dieselRME (rapeseed methyl ester) blends with EGR (exhaust gas recirculation). Energy. 2007;32:2072-80. 